\title{
PEMODELAN KASUS HIV/AIDS MENGGUNAKAN COX PROPORTIONAL HAZARD
}

\author{
Rama Hiola ${ }^{(1)}$, Bambang Widjanarko Otok ${ }^{(2)}$, HendraDukalang ${ }^{(3)}$ \\ ${ }^{(1)}$ Faculty Science Health and Sportmanship, University Country of Gorontalo, Gorontalo, \\ (2) (3) Laboratory of Environmental and Health Statistic, 'Sepuluh Nopember' Institute of \\ Technology (ITS), Surabaya \\ e-mail: ${ }^{(1)}$ hiola_rama@gmail.com, ${ }^{(2)}$ dr.otok.bw@gmail.com
}

\begin{abstract}
ABSTRAK
Aktivitas kehidupan banyak peristiwa yang berhubung dengan waktu kelangsungan hidup, misal durasi waktu yang dibutuhkan untuk sembuh dari penyakit. Lama waktu yang dibutuhkan hingga terjadinya suatu peristiwa tertentu itulah yang disebut waktu survival. Pada umumnya data waktu survival tidak sepenuhnya dapat diamati atau disebut dengan data tersensor. Salah satu metode statistika yang dapat digunakan dalam menganalisis data survival, adalah model cox proportional hazard. Penelitian ini bertujuan untuk mengetahui tingkat kelangsungan hidup penderita HIV/AIDS, digunakan fungsi hazard dan fungsi survival dengan variabel lama rawat inap pasien sebagai respon. Untuk mengetahui faktor-faktor lain yang mempengaruhi ketahan hidup penderita HIV/AIDS digunakan model cox proportional hazard. Hasil penelitian menunjukkan bahwa Hasil Estimasi fungsi survival Kaplan Meier dan fungsi hazard kumulatif Nelson Aalen menunjukan bahwa semakin lama pasien menderita HIV/AIDS maka probabilitas survival pasien semakin kecil, namun resiko kematian disebabkan HIV/AIDS semakin tinggi. Tingkat pendidikan, status pekerjaan, status fungsional, Kadar CD4 merupakan faktor yang berpengaruh dalam resiko kematian pasien HIV/AIDS.
\end{abstract}

Kata kunci : Analysis survival, Cox Proportional Hazard, HIV/AIDS.

\section{PENDAHULUAN}

Human Immunodeficiency Virus (HIV) merupakan salah satu virus yang menurunkan system kekebalan tubuh sehingga orang yang terkena virus ini akan menjadi rentan terhadap berbagai infeksi dan kemudian menyebabkan Acquired Immuno Defisiency Syndrome (AIDS).Diperkirakan 5 -10 juta pengidap HIV yang belum menunjukkan gejala apapun tetapi potensial sebagai sumber penularan(Wibisono B, 1989). AIDS adalah suatu penyakit yang sangat berbahaya karena mempunyai case fatality rate $100 \%$ dalam 5 tahun, artinya dalam waktu 5 tahun setelah diagnosa AIDS dilakukan maka semua penderita akan meninggal.Faktor-faktor yang mempengaruhi kelangsungan hidup penderita HIV/AIDS yaitu Umur, jenis kelamin, tingkat pendidikan, status pekerjaan, status perkawinan, riwayat ARV, kadar CD4 absolut, infeksi oportunistik, status fungsional, stadium dan kepatuhan terapi(Saputro. A. S. ,2013).

Penelitian yang berkaitan dengan analisis survival adalah factor-faktor yang mempengaruhi kejadian pada kasus (DBDPurhadi,2012). Penelitian tentang pemodelan mixture survival untuk kasus HIV/AIDS di RSUP Dr. Kariadi Semarang yang lebih ditekankan pada upaya penurunan kasus HIV/AIDS dan bagaimana respon penyembuhan penyakit HIV/AIDS(Saputro. A. S., 2013)

Analisis survival merupakan salah satu metode statistika yang dapat digunakan untuk menganalisis data yang berhubungan dengan waktu mulai (time origin) atau start point sampai terjadinya suatu peristiwa khusus (end point) atau failure event(Collect, D., 2003).Analisis survival digunakan untuk menganalisis data atau kasus yang berhubungan dengan lamanya waktu hingga terjadi suatu peristiwa tertentu dan adanya data tersensor (Kleinbaum. D. G., 2012). Studi survival difokuskan pada prediksi probabilitas respon, survival, rata-rata harapan hidup, dansekarang berkembang pada identifikasi faktor resiko dan faktor prognostik yang berhubungan dengan penyakit(Lee, E.T.,2003). Salah satu metode analisis yang dapat digunakan untuk data survival adalah regresi cox proportional hazard (cox PH) (Cox, D. R., 1972).

Human Immunodeficiency Virus (HIV) merupakan salah satu virus yang menurunkan system kekebalan tubuh sehingga orang yang terkena virus ini akan menjadi rentan terhadap berbagai infeksi dan kemudian menyebabkan Acquired Immuno 
Defisiency Syndrome (AIDS)(Saputro. A. S., 2013)(Wibisono B, 1989). Untuk mengetahui faktor-faktor yang mempengaruhi kelangsungan hidup HIV/AIDSdigunakan pendekatan Cox Proportional Hazard.

\section{METODE PENELITIAN}

Pada Sumber data yang digunakan dalam penelitian adalah data sekunder (Cox, D. R., 1972). Data berupa rekam medis penderita HIV/AIDS yang di mulai dari Januari 2008 sampai dengan Desember 2012, dimana semua variabel prediktor diukur di ukur diawal terdiagnosis HIV/AIDS. Jumlah data sebanyak 90 pasien. Variabel yang digunakan dalam penelitian ini adalah (Cox, D. R., 1972):

Y : Waktu Survival (Bulan)

$\mathrm{X}_{1}$ :Umur (tahun)

$\mathrm{X}_{2}$ : Jenis kelamin (1= perempuan, 2=laki-laki,

$\mathrm{X}_{3}$ : Tingkat pendidikan (1=SMA s/d PT, $2=\mathrm{SD}$ s/d SMP, 3=Tidak Sekolah)

$\mathrm{X}_{4}$ : Status pekerjaan (1=bekerja, $2=$ tidak bekerja)

$\mathrm{X}_{5}$ : Status perkawinan (1=kawin, $2=$ belum kawin)

$\mathrm{X}_{6}$ : Riwayat ARV (1=pernah, 2=belum pernah)

$\mathrm{X}_{7}$ : Kadar CD4 absolut

$\mathrm{X}_{8}$ : Infeksi oportunistik (1=terinfeksi, 2=tidak terinfeksi)

$\mathrm{X}_{9}$ : Status Fungsional (1=Normal, 2=Ambulatori, $3=$ Berbaring)

$\mathrm{X}_{10}$ : Stadium (1=Stadium I, 2=Stadium II, $3=$ Stadium III, 4=Stadium IV)

$\mathrm{X}_{11}$ : Kepatuhan Terapi (1=Patuh, 2=tidak patuh)

Adapun langkah-langkah dalam penelitian ini adalah deskripsi karakteristik pasien HIV/AIDS, pengujian kurva survival dan log rank, pengujian asumsi cox proportional hazard dan mengestimasi fungsi survival dan fungsi hazard komulatif (Lee, E.T. (2003).

\section{HASIL DAN PEMBAHASAN \\ I. Deskriptif Pasien HIV/AIDS}

Statistika deskriptif digunakan untuk menggambarkan karakteristik pasien berdasarkan faktor-faktor yang diduga mempengaruhi survival pasien HIV/AIDS. Tabel 1 menyatakan hasil statistika deskriptif yang meliputi waktu survival, faktor umur, dan kadar CD4 disajikan dalam bentuk mean, varians, minimum, dan maksimum.

Tabel 1 Deskriptif Variabel Prediktor yang Kontinu

\begin{tabular}{ccccc}
\hline Variabel & Mean & Varians & Min & Maks \\
\hline Waktu survival (bulan) & 18,67 & 357,96 & 1 & 57 \\
Umur (Tahun) & 29,21 & 140,08 & 1 & 67 \\
Kadar CD4 (sel/mm $\left.\mathrm{mm}^{3}\right)$ & 134,00 & 15340,34 & 13 & 485 \\
\hline
\end{tabular}

485

Tabel 1, dapat memberikan informasi bahwa rata-rata waktu survival pasien HIV/AIDS adalah 18,67 bulan atau sekitar 1,5 tahun dengan waktu minimal adalah 1 bulan dan maksimal 57 bulan. Pasien juga rata-rata berumur 29,21 tahun, selain itu, diperoleh hasil bahwa pasien yang paling muda berumur 1 tahun, dan yang yang paling tua berumur 67 tahun. Untuk kadar CD4, rata-rata pasien

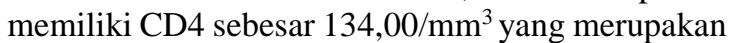
kondisi tidak normal jika dinadingkan dengan jumlah CD4 kondisi normal sebesar $=350 / \mathrm{mm}^{3}$.

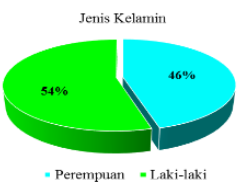

(a)

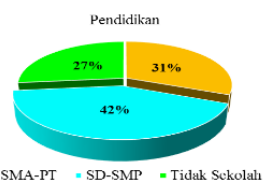

(b)

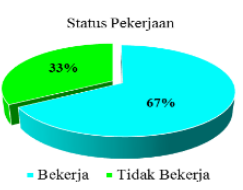

(c)

Gambar 2KarakteristikPasien HIV/AIDS berdasarkan a). Jenis Kelamin, b). Tingkat Pendidikan, c). Status Pekerjaan

Gambar 2 Mayoritas pasien HIV/AIDS berjenis kelamin laki-laki sebanyak 49 pasien (54\%) dan pasien berjenis kelamin perempuan sebanyak 41 pasien $(46 \%)$, dengan tingkat pendidikannya SDSMP sebanyak 38 pasien (42\%), SMA-PT sebanyak 28 pasien $(31 \%)$ dan yang tidak sekolah sebanyak 24 pasien $(27 \%)$, serta status bekerja 60 pasien (67\%), dan tidak bekerja sebanyak 30 pasien (33\%).

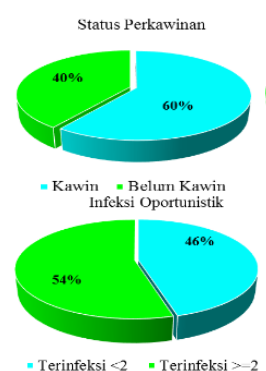

(a)

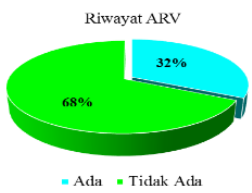

(b) (c)

Gambar 3. KarakteristikPasien HIV/AIDS berdasarkan a). Status Perkawinan, b).Riwayat ARV, c). Infeksi Oportunistik

Gambar 3 (a) menunjukkan bahwa mayoritas pasien HIV/AIDS sudah kawin sebanyak 54 pasien (60\%) dan pasien yang belum kawin sebanyak 36 pasien ( $40 \%)$, dengan pasien tidak ada riwayat ARV sebanyak 61 pasien (68\%), dan yang ada riwayat ARV sebanyak 29 pasien (32\%) serta pasien sudah terinfeksi Oportunistik < 2 sebanyak 41 pasien (46\%) lebih sedikit dibandingkan dengan pasien yang terinfeksi oportunistik $\geq$ sebanyak 49 pasien (54\%).

Pada Gambar 4 (a). menunjukkan mayoritas pasien HIV/AIDS dengan status normal sebanyak 38 pasien $(42 \%)$, dan pasien dengan status berbaring 
sebanyak 36 pasien (40\%), serta pasien dengan status ambulatori sebanyak 16 pasien (18\%), sedangkan pasien dengan stadium I sebanyak 32 pasien (36\%), stadium II sebanyak 17 pasien (19\%), stadium III sebanyak 22 pasien (24\%), dan stadium IV sebanyak 19 pasien (21\%). Serta pasienyang patuh pada terapi ART sebanyak 58 pasien (64\%) dan pasien yang tidak patuh pada terapi sebanyak 32 pasien $(36 \%)$.

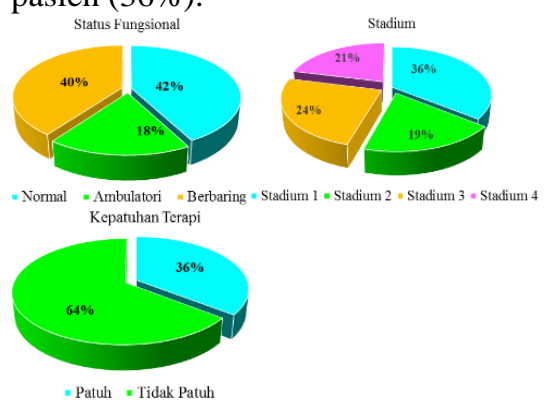
Status Fungsional, b). Stadium Klinis, c). Kepatuhan Terapi

\section{Pemodelan Cox PH pada pasien HIV/AIDS \\ a. Analisis Kurva Survival Kaplan Meier dan Uji Log Rank. \\ Gambar 5 menunjukkan bahwa probabilitas} ketahanan hidup pasien HIV/AIDS pada bulan ke-0 hingga bulan ke-15 masih tinggi berkisar antara 0,5 sampai 1. Namun pada bulan ke-16 kurva survival turun lambat hingga pada bulan ke 57. Pada rentang waktu tersebut, peluang survival pasien HIV/AIDS berkisar antara 0,35 hingga 0,5.

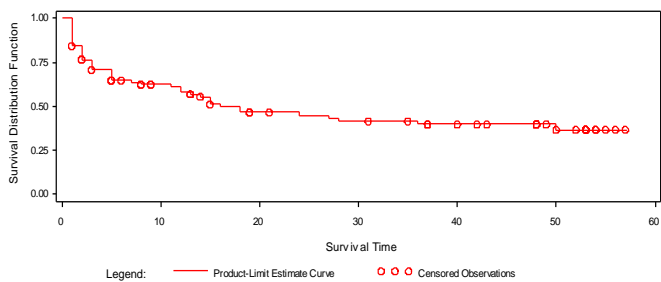

Gambar 5 Kurva Survival Kaplan Meier Pasien HIV/AIDS

Untuk menguji hipotesis apakah terdapat perbedaan antara kurva survival pasien HIV/AIDS berdasarkan variabel-variabel prediktor, maka perlu dilakukan uji log rank yang disajikan pada Tabel 2.

\begin{tabular}{ccccc}
\hline Pendidikan & $\mathbf{6 , 9 3 2 0}$ & $\mathbf{2}$ & $\mathbf{0 , 0 3 1 2}$ & Tolak $\boldsymbol{H}_{\boldsymbol{0}}$ \\
\hline Pekerjaan & 0,7075 & 1 & 0,4003 & Gagal Tolak $H_{0}$ \\
\hline Perkawinan & 1,6986 & 1 & 0,1925 & Gagal Tolak $H_{0}$ \\
\hline Riwayat ARV & 1,0034 & 1 & 0,3165 & Gagal Tolak $H_{0}$ \\
\hline Kadar CD4 & $\mathbf{1 2 , 6 2 7 0}$ & $\mathbf{2}$ & $\mathbf{0 , 0 0 1 8}$ & Tolak $\boldsymbol{H}_{\boldsymbol{o}}$ \\
\hline $\begin{array}{c}\text { Infeksi } \\
\text { Oportunistik }\end{array}$ & $\mathbf{1 7 , 0 4 7 9}$ & $\mathbf{1}$ & $<\mathbf{0 , 0 0 0 1}$ & Tolak $\boldsymbol{H}_{\boldsymbol{\theta}}$ \\
\hline $\begin{array}{c}\text { Status } \\
\text { Fungsional }\end{array}$ & $\mathbf{2 7 , 5 8 4 8}$ & $\mathbf{2}$ & $<\mathbf{0 , 0 0 0 1}$ & Tolak $\boldsymbol{H}_{\boldsymbol{\theta}}$ \\
\hline Stadium & $\mathbf{2 3 , 3 0 3 4}$ & $\mathbf{3}$ & $<\mathbf{0 , 0 0 0 1}$ & Tolak $\boldsymbol{H}_{\boldsymbol{0}}$ \\
\hline Kepatuhan & $\mathbf{5 4 , 0 3 5 0}$ & $\mathbf{1}$ & $<\mathbf{0 , 0 0 0 1}$ & Tolak $\boldsymbol{H}_{\boldsymbol{0}}$ \\
\hline
\end{tabular}

Tabel 2menunjukkan bahwa nilai uji log rank untuk variabel, umur, jenis kelamin, pekerjaan, perkawinan, dan riwayat ARV mempunyai nilai $p$ value lebih besar dari 0,05. Denganmenggunakan $\alpha$ sebesar 0,05 diperoleh keputusan $H_{0}$ gagal tolak yang berarti tidak terdapat perbedaan yang signifikan antara kurva survival dengan pasien HIV/AIDS. Sedangkan untuk variabel pendidikan, Kadar CD4, Infeksi Oportunistik, Status Fungsional, Stadium, dan Kepatuhan Terapi mempunyai nilai $p$-value kurang dari 0,05 . sehingga keputusannya $H_{0}$ tolak yang berarti terdapat perbedaan yang signifikan antara kurva survival pasien HIV/AIDS pada variabel tersebut.

\section{b. Pengujian Asumsi Proportional Hazard}

Pengujian dengan menggunakan plot $\ln (-\ln \widehat{S}(t))$

Berdasarkan hasil plot $\ln (-\ln \hat{S}(\mathrm{t}))$ seluruh variabel diduga memenuhi asumsi proportional hazard. Akan tetapi pendugaan asumsi proportional hazard dengan pendekatan grafik biasanya menghasilkan keputusan yang berbeda antara satu pengamat dan pengamat yang lain, sehingga perlu digunakan pendekatan lain yang lebih dapat menguatkan keputusan apakah asumsi proportional hazard terpenuhi atau tidak. Salah satu pendekatan statistik yang dapat digunakan adalah pengujiam dengan menggunakan goodness of fit (GOF)

\section{Pengujiam dengan menggunakan goodness of fit}

Goodness of fit untuk setiap faktor yang diduga mempengaruhi ketahanan hidup penderita HIV/AIDS ditunjukan pada Tabel 3 berikut.

Tabel 3. Pengujian asumsi Proportional Hazard dengan GOF

Tabel 2. Uji Log Rank untuk variabelpredictor

\begin{tabular}{lccc}
\hline \multicolumn{1}{c}{ Variabel } & Korelasi & p-value & Keputusan \\
\hline Umur & $-0,105$ & 0,474 & Gagal Tolak $H_{0}$ \\
Jenis Kelamin & $-0,174$ & 0,233 & Gagal Tolak $H_{0}$ \\
Tingkat Pendidikan (2) & $-0,006$ & 0,967 & Gagal Tolak $H_{0}$ \\
Tingkat Pendidikan (3) & 0,184 & 0,205 & Gagal Tolak $H_{0}$ \\
$H_{0}$ Status Pekerjaan & $-0,130$ & 0,372 & Gagal Tolak $H_{0}$
\end{tabular}

Rama Hiola ${ }^{1}$, Bambang Widjanarko Otok ${ }^{2}$, HendraDukalang ${ }^{3} /$ J Statistika Vol. I No. ...,,(2016) 


\begin{tabular}{lccl} 
Status Perkawinan & 0,166 & 0,255 & Gagal Tolak $H_{0}$ \\
Riwayat ARV & 0,017 & 0,906 & Gagal Tolak $H_{0}$ \\
Kadar CD4 Absolut & $-0,054$ & 0,710 & Gagal Tolak $H_{0}$ \\
Infeksi Oportunistik & 0,046 & 0,755 & Gagal Tolak $H_{0}$ \\
Status Fungsional (2) & $-0,025$ & 0,866 & Gagal Tolak $H_{0}$ \\
Status Fungsional (3) & 0,198 & 0,173 & Gagal Tolak $H_{0}$ \\
Stadium (2) & $-0,232$ & 0,108 & Gagal Tolak $H_{0}$ \\
Stadium (3) & $-0,005$ & 0,974 & Gagal Tolak $H_{0}$ \\
Stadium (4) & 0,137 & 0,349 & Gagal Tolak $H_{0}$ \\
Kepatuhan & 0,046 & 0,752 & Gagal Tolak $H_{0}$ \\
\hline$* \alpha=0,05$ & & &
\end{tabular}

Tabel 3 menunjukkan bahwa Laju terjadinya kematian pada penderita HIV/AIDS dikatakan konstan atau tidak bergantung kepada waktu, jika tidak ada korelasi yang besar antara faktor yang diduga mempengaruhi daya tahan hidup pasien HIV/AIDS dengan waktu survival. Berdasarkan Tabel 3semua variabel tidak memiliki korelasi yang tinggi dengan waktu survival. Dengan menggunakan $\alpha=0,05$ maka semua variabel korelasinya tidak signifikan sehingga asumsi proportional hazard terpenuhi.

\section{c. Estimasi fungsi survival dan fungsi hazard kumulatif}

Estimasi fungsi survival dan fungsi hazard kumulatif diperoleh berdasarkan metode KaplanMeier, dimana untuk estimasi fungsi hazar kumulatif menggunakan estimasi Nelson Aalen. Hasil estimasi fungsi survival dapat dilihat pada Tabel 4.

Tabel 4. Estimasi Fungsi Survival dan Fungsi Hazard Kumulatif

\begin{tabular}{ccc}
\hline Survival time & $S(t)$ & $\Lambda(t)$ \\
\hline 1 & 0,844 & 0,156 \\
2 & 0,766 & 0,249 \\
3 & 0,708 & 0,325 \\
5 & 0,649 & 0,408 \\
7 & 0,636 & 0,427 \\
8 & 0,634 & 0,447 \\
11 & 0,610 & 0,469 \\
12 & 0,583 & 0,513 \\
13 & 0,569 & 0,536 \\
14 & 0,555 & 0,561 \\
15 & 0,511 & 0,640 \\
16 & 0,496 & 0,670 \\
18 & 0,466 & 0,730 \\
24 & 0,450 & 0,766 \\
27 & 0,433 & 0,803 \\
28 & 0,416 & 0,841 \\
36 & 0,398 & 0,885 \\
50 & 0,368 & 0,962 \\
\hline
\end{tabular}

Tabel 4, menunjukkan bahwa semakin lama pasien HIV/AIDS dirawat di rumah sakit, maka probabilitas kematian (fungsi survival) pasien HIV/AIDS semakin kecil. Namun sebaliknya, Jika semakin lama pasien HIV/AIDS dirawat di rumah sakit maka resiko kematian (fungsi hazardnya) semakin tinggi. Hal ini dapat menjelaskan bahwa probabilitas kelangsungan hidup penderita HIV/AIDS berbanding terbalik dengan tingkat kelangsungan hidup penderita HIV/AIDS.

\section{d. Pendugaan Distribusi Data Survival}

Berdasarkan pengujian distribusi dengan menggunakan Uji Anderson Darling diperoleh bahwa data waktu survival berdistribusi Weibull dengan 2 parameter. Parameter yang digunakan dalam model adalah $\hat{\eta}=0.8024$ dan $\hat{\gamma}=16.779$. Parameter ini digunakan untuk mendapatkan fungsi baseline hazard dengan persamaan berikut:

$$
\begin{aligned}
\lambda_{0}(t \mid \hat{\eta}, \hat{\gamma}) & =\frac{\hat{\gamma}}{\hat{\eta}}\left(\frac{t}{\hat{\eta}}\right)^{\hat{\gamma}-1} \\
& =\frac{16,779}{0,80247}\left(\frac{t}{0,80247}\right)^{16,779-1}=20,909\left(\frac{t}{0,859}\right)^{15,779}
\end{aligned}
$$

Persamaan (18) merupakan baseline hazard yang akan digunakan dalam pemodelan Cox Proportional Hazard.

\section{KESIMPULAN DAN SARAN \\ Kesimpulan}

Berdasarkan hasil analisi dan pembahasan, maka menghasilkan beberapa kesimpulan, yaitu:

1. Hasil Estimasi fungsi survival Kaplan Meier dan fungsi hazard kumulatif Nelson Aalen menunjukan bahwa semakin lama pasien menderita HIV/AIDS maka probabilitas survival pasien semakin kecil, namun resiko kematian disebabkan HIV/AIDS semakin tinggi.

2. Pendidikan, pekerjaan, kadar CD4, dan status fungsional faktor yang berpengaruh terhadap survival pasien HIV/AIDS

\section{Saran}

Berdasarkan hasil analisis yang telah dilakukan maka dapat disarankan bahwa dalam pembentukan model Cox PH mensyaratkan asumsi proportional hazard harus terpenuhi, namun jika asumsi tidak terpenuhi maka dapat menggunakan pendekatan regresi cox extended. 


\section{DAFTAR PUSTAKA}

Collect, D. (2003). Modeling Survival Data in Medical Research. London: Chapman \& Hall/CRC

Cox, D. R. (1972). Regresion Model and Live Tables (withdiscussion), Journal of The Royal Statistical Society, 34 : 187-220

Kleinbaum. D. G. (2012). Survival Analisis, London, Springer

Lee, E.T. (2003). Statistical Method for survival Data Analysis. London John Willey

Purhadi. (2012). Analisis Survival Faktor-faktor yang mempengaruhi Laju kesembuhan pasien Penderita Demam Berdarah Dengue (DBD) di RSU Haji Surabaya dengan Regresi Cox. Jurnal Sains dan Seni ITS, Volume I. No. I., 271-267

Saputro. A. S. (2013) pemodelan mixture survival untuk kasus HIV/AIDS. Universitas Airlangga. Surabaya

Wibisono B, (1989). Epidemiologi AIDS; petunjuk untuk petugas kesehatan, Departemen Kesehatan RI. Jakarta.

Rama Hiola ${ }^{1}$, Bambang Widjanarko Otok ${ }^{2}$, HendraDukalang ${ }^{3} /$ J Statistika Vol. I No. ...,,(2016) 
